\title{
Katja Seutu
}

morality in

\section{Puheenomaisen runon rakenteesta}

aschaftliche

Imirabilium

Noviomagi

ralium quae

pictura $\mathrm{Oy}$. a Forgotten

Tarkastelen artikkelissani Maila Pylkkösen teosta Arvo. Vanhä̈iti puhuu runonsa (1959) puheenomaisena runoteoksena. Olen kiinnostunut siitä, kuinka puheen vaikutelma syntyy runossa ja millaisin erilaisin tavoin puhe ja runo voivat kytkeytyä toisiinsa.

Maila Pylkkönen (1931-1986) julkaisi esikoiskokoelmansa Klassilliset tunteet vuonna 1957. Teos sai myönteisen vastaanoton, ja Pylkkönen vakiinnutti pian asemansa suomenkielisen lyriikan modernismin yhtenä kärkihahmona. Pylkkösen tuotanto koostuu kymmenestä teoksesta, joista viimeinen, On kesä vain, ilmestyi vuonna 1977. Pylkkönen oli kirjailijana itsenäinen oman tiensä kulkija, vaikka aikalaiskriitikot havaitsivatkin ensimmäisissä teoksissa Paavo Haavikon ja Eeva-Liisa Mannerin vaikutusta. Kaksi ensimmäistä teosta, Klassilliset tunteet ja Jeesuksen kylä, pohjustavat myöhemmissäkin teoksissa keskeisiä kysymyksiä, kuten naiskirjailijan suhdetta traditioon, toisen ihmisen merkitystä ja kirjailijan suhdetta kieleen.

Arvo on Maila Pylkkösen kolmas runoteos ja ensimmäinen hänen kirjoittamistaan monologeista. Arvon runojen puhuja on otsikon mukaisesti vanhaäidiksi kutsuttu vanhus, joka kertoilee nykyisen ja menneen elämänsä vaiheita. Teoksen alaotsikon omistusliitteinen runonsa viittaa Arvon elämäkerıalliseen painotukseen - vanhaäidillä on omistussuhde siihen, mitä hän puhuu. Vanhaäidin fiktiivisen elämäkerran merkittävimpiä ja samalla traagisimpia käännekohtia ovat kotitalon tuhoutuminen sodassa, miehen kuolema, sairastuminen vanhalla iällä ja sairastumista seurannut riippuvuus eri hoitajista. Muut Pylkkösen monologit ovat ilmestyneet Arvoa seuraavissa teoksissa Ilmad ja Valta. Pylkkösen puheenomaiset monologit ovat kiinnostava ja epätavallinen ilmiö jo siksi, että monologeja ei ole suomenkielisessä modernistisessa runoudessa kirjoitettu kovinkaan systemaattisesti. Mainittujen teosten puhujat ovat cri-ikäisiä naishenkilöitä, jotka esitellään teosten alaotsikoissa. ${ }^{1}$

Vuodesta 1965 lähtien Pylkkösen tuotannon profili muuntuu melko radikaalisti. Teoksen Valta jälkeen ilmestyneitä teoksia Virheitä, Tarina tappelusta, Muistista ja Marjamiesnaisen muistiinpanoja yhdistää runoilijaroolinen minäkertoja/runon puhuja, joka elää arkipäiväänsä 60- ja 70-lukujen Helsingissä. Käytännössä tämä tarkoittaa, että 
mainittujen teosten puhuja-asemaa hallitsee yksi ja sama henkilö, kun taas ennen vuotta 1965 ilmestyneissä teoksissa puhujat vaihtuvat teoksesta toiseen. Mainitut teokset poikkeavat niitä edeltävistä teoksista myös siten, että ne ovat hallitsevasti proosamuotoisia: Virheitä ja Tarina tappelusta sisältävät lähes yksinomaan lyhyehköä proosaa, ja teoksissa Muistista ja Marjamiesnaisen muistiinpanoja säe- ja proosamuotoista tekstiä esiintyy rinnakkain. ${ }^{2}$ Viimeisessä kokoelmassa On kesä vain palataan tiiviiseen säemuotoiseen ilmaisuun.

Maila Pylkkösen teoksille on ominaista naishenkilöiden puheen korostuminen. Tuula Hökkä $(1989,620)$ on todennut tämän kirjoittaessaan, että "kulttuuritradition marginaalissa eläville, lapsille, vanhuksille, naisille ja mielisairaille, äänen antaminen tulee [--] Pylkkösen oman runoilijalaadun avaajaksi". Hökkä (1987) luonnehtiikin Pylkkösen runoutta "puherunoksi". Myös arki, joka on ymmärrettävissä naishenkilöiden arkipäivän kuvaukseksi, aiheiston arkisuudeksi ja arkikielisyydeksi, yhdistää teoksia.

Kun Arvod tarkastellaan suomenkielisen 50-luvun lyriikan modernismin kontekstissa, on tarpeen arvioida, mitä uutra Arvo puhekielisenä ja aiheistoltaan arkisena tuo vallitseviin käsityksiin modernistisesta runosta (vrt. Hökkä 1992, 89). Arvon voi katsoa edustavan sekä modernistista että puheenomaisen runouden traditioon kytkeytyvää teosta. Tuula Hökkä $(1999,86)$ on huomioinut uusimman kirjallisuushistorian modernismi-luvussa puheenomaisen runouden, joskin melko implisiittisesti. Jo aiemmin Auli Viikari $(1981,195)$ on esittänyt, että puheenomainen runous on yksi modernin runouden perinne. Myös oma näkemykseni on, että puheenomaisuus ei ole yksinomaan modernistisen runouden ilmiö, vaan sen juuret ulottuvat pidemmälle. ${ }^{3}$ Oletus modernistisesta puheenomaisesta runoudesta haastaakin tutkimaan, millaisin erilaisin tavoin puheenomaisuus toteutuu juuri modernistisessa 50-luvun runoudessa. Onhan esimerkiksi myös Paavo Haavikon runouden puheenomaisuuteen viitattu (Viikari 1981, 198; Launonen 1984, 102).

Mirjam Polkusen (1959) Arvon aikalaiskritiikissä esittämä kysymys "onko syntynyt reaktio yksinomaan silmälle tarkoitettua runoa vastaan" vihjaa toiseen Arvon kirjallisuushistoriallista asemaa koskevaan aspektiin. Arvo edustaa paitsi yhtä 50-luvun modernistisen runouden marginaaliin jäänyttä traditiota myös 50- ja 60-lukujen taitteen teosta, joka sisältää muutoksen siemenen. Arvo ennakoi runoilmaisun muutoksia, jotka tulevat varsinaisesti näkyviin 60- ja 70-lukujen puheenomaisessa ja kantaaottavassa runoudessa. Onhan puhekielisen ilmaisun yhdistymistä arkiseen aiheistoon ja "silmälle tarkoitetun" kuvakeskeisyyden vähenemistä tavattu pitää pikemminkin 60- kuin 50luvun runoudelle ominaisena piirteenä.

Tässä artikkelissa määrittelen Arvon puheenomaisuuden seuraavasti: Arvo on puheen illuusiota tuottava teos, jossa hyödynnetään puhutun kielen piirteitä. Puhuja ja puhetapahtuma, jotka on ilmaistu myös otsikossa, ovat teoksessa kohosteisesti esillä. 
ennen vuotitut teokset roosamuoproosaa, ja oista tekstiä en säemuo-

ostuminen. uritradition taminen tutiikin Pylknenkilöiden à teoksia.

in konteksrkisena tuo $n$ voi katsoa keytyvää teian moderemmin Auli odernin ruksinomaan tus moderaisin tavoin han esimer1981, 198;

ko syntynyt von kirjalli-luvun mojen taitteen oksia, jotka ttavassa ruja "silmälle 0 - kuin 50-

Arvo on pui. Puhuja ja isesti esillä.
Puheenomaisuus ilmenee myös runojen sisäisessä rakenteessa ja runojen välisissä kytkennöissä ja se motivoituu teoskokonaisuudesta käsin.

Arvon puheenomaisuus on moniaalle haarovaa. Se voidaan nähdä teoksen kantavana poeettisena periaatteena, jota kutsun "puheen poetiikaksi". Teoksen alaotsikkoon sisältyvä puhud-verbi vihjaa puhujan ja puhetapahtuman keskeisyyteen: vanhaäidin puhe, teoksessa jatkuvasti keskeinen puhetilanne, rakentaa teoksen maailman. Kaikki toiminta ja teoksen muut henkilöt tulevat esiin ainoastaan vanhaäidin puheessa: vanhaäiti on kertoja, joka esittää toisten henkilöiden puhetta suoran ja epäsuoran esityksen keinoin. Niin ikään on keskeistä, että vanhaäidille ominainen tapa käyttää kieltä, vanhaäidin fiktiivisen puheen idiolekti, rakentaa henkilöhahmon persoonaa. Vanhaäidin idiolekti rakentuu useista puhutun kielen piirteistä, joista tässä mainittakoon esimerkkeinä vain loppuheitto, kuten "kyllä toi unen saaminen osas olla vaikeaa" (Arvo, 9), henkilöviittaukset pronominilla se pronominin bän sijasta, kuten "hoitaja sanoo pöllöks, kun se on pahalla päällä" (Arvo, 13) ja hämäläismurteille ominainen sanasto (etenkin nä̈̈s ja aartikas).

Keskityn artikkelissani tutkimaan, miten puheenomaisuus ilmenee Arvon runojen rakenteessa. Esitän ensin yleisempiä huomioita kaunokirjallisen tekstin puheenomaisuudesta. Luvussa "Arvon säeyksikköjen rakentumisen periaatteita" tutkin, miten $A r-$ von runojen semanttista tasoa hallitseva henkilöiden välinen kommunikaatio ja elämäkerralliset kertomukset vaikuttavat runoille ominaisten säeyksikköjen rakentumisen periaatteisiin. Analysoin Arvon runoille ominaisia säeyksikköjä soveltamalla runoanalyysiin kielitieteellistä lausuma-analyysia: tutkin säeyksikköjä puhetoimintoina. Luvussa "Runojen väliset kytkennät ja puheen esittämisen merkitys" laajennan rakenteellista näkökulmaa runojen välisiin kytkentöihin ja pohdin puheen esittämisen merkitystä Arvon teoskokonaisuuden kannalta.

\section{Kaunokirjallisen tekstin puheenomaisuudesta}

Puheenomaista runoa ei ole juurikaan tutkittu suomalaisessa kirjallisuudentutkimuksessa, vaikka useissa lyriikantutkimuksissa onkin tavalla tai toisella kiinnitetty huomiota runouteen kielellisestä näkökulmasta. ${ }^{4}$ Poikkeuksen muodostaa Auli Viikarin (1987, 54-62) väitöskirja, jonka runon pragmaattista tasoa käsittelevässä jaksossa selvitetään puhujuuden problematiikkaa ja kiinnitetään huomio runon vuorovaikutukselliseen luonteeseen. Suomen kielen tutkijoita kaunokirjallisuuden tutkiminen kielellisestä näkökulmasta on kiinnostanut enemmän. ${ }^{5}$

Kaunokirjallinen teksti mielletään puheenomaiseksi etenkin silloin, kun se on ilmaisultaan arkikielinen - kun siinä esiintyy mitä tahansa puhutulle kielelle ominaisia piirteitä enemmän tai vähemmän systemaattisesti ja kohosteisesti. Puheenomaisuus voidaan ymmärtää myös laajemmin. Vaikka Arvon runoista on helposti erotettavissa 
erilaisia toistuvia puhekielisyyksiä, ne eivät sinänsä herätä riittävää motivaatiota tutkia teoksen puheenomaisuutta, joka on ilmiönä paljon monisyisempi. Puheenomaisuus ilmenee kaunokirjallisissa teksteissä eri tavoin. Puheen vaikutelma voi rakentua yhden tai useamman piirteen varassa. Saman runoteoksen runot voivat olla puheenomaisia toisistaan poikkeavilla tavoilla, tai sitten puheenomaisuus voi ilmetä teoskokonaisuudesta käsin katsottuna yhtenäisinä periaatteina, kuten Arvossa. Myös selkeästi ilmaistua puhujapositiota on pidetty itsessään yhtenä puheenomaisuuden tunnusmerkkinä (vrt. Launonen 1984, 102; Viikari 1981, 200).

Puheenomaisuus voi perustua paitsi puhekielisyyksiin myös muunlaisiin melko helposti havaittaviin ratkaisuihin. Viikari $(1981,198)$ on kiinnittänyt huomiota siihen, miten välimerkkien poikkeava käyttö voi olla runossa keino jäljitellä puheen rytmiä. Viikarin antama esimerkki "kuunnellusta pilkutuksesta" on sitaatti Paavo Haavikon Synnyinmaasta $(1955,23)$ :

$[--]$

se ihmettelee, ja kun se ihmettelee, se nauraa, kun se nauraa,

se kaatuu, ja kun se kaatuu se kaatuu niin kuin tammi kun tammet kaatuvat, $[--]$

Kaunokirjallisen tekstin puheenomaisuus voi toki ilmetä myös implisiittisemmin tavoilla, joiden näkyväksi saattaminen vaatii paneutumista teoksen tai tuotannon poeettisiin periaatteisiin.

Kaunokirjallisen tekstin puheenomaisuuden toteaminen ei sinänsä riitä. Aina on myös kysyttävä, mitä sillä "tehdään". Kirjoitetun tekstin puheenomaisuus on efekti, jonka avulla tuotetaan autenttisen puheen vaikutelmaa - illuusiota, että kaunokirjallisessa tekstissä toteutuu puheakti tässä ja nyt. Oleellista on selvittää tapauskohtaisesti, mikä merkitys puheen vaikutelman syntymisellä on kussakin kontekstissa. (Ks. Kalliokoski 1991,$158 ; 1998$.) Puheen vaikutelman tuottaminen on retorinen keino, joka palvelee esimerkiksi runon tai teoskokonaisuuden ideologista tasoa, kuten yhteiskunnallisesti kantaaottavassa runoudessa.

Puheenomaisuus ei ole luonnollisestikaan vain runouden ominaispiirre. Pikemminkin voidaan ajatella, että puheenomaisuus on proosassa tavanomaisempaa kuin runoudessa: pyritäänhän proosakerronnan dialogeissa yleensä rakentamaan autenttisen puheen vaikutelmaa. Esimerkiksi Marja-Liisa Vartion romaanissa Kaikki naiset näkevät unia puhutun kielen piirteiden hyödyntäminen henkilöiden välisissä dialogeissa vahvistaa autenttisen puheen vaikutelmaa.

- Taiteilijat ovat aina eläneet köyhyydessä, oikeat taiteilijat, sanoi Kirsti Högström. - Köyhänähän se kuoli se Kivikin, vai hulluksiko se tuli?

- Niin, katsotaan vain, mihin tämä kaikki vie. Johan se on nähty, sanoi rouva 
tiota tutkia

enomaisuus

entua yhden

leenomaisia

cokonaisuu-

sti ilmaistua

rkkkinä (vrt.

isiin melko iota siihen, een rytmiä. Haavikon

tuvat,

semmin tainon poeet-

tä. Aina on s on efekti, Iunokirjallikohtaisesti, a. (Ks. Kalkeino, joka yhteiskunrre. Pikemaa kuin ruautenttisen iiset näkevät ogeissa vah-

Viita.

- Jos annettaisiin niin ottaisin pahus vie minäkin, sanoi rouva Viidan mies ja nauroi. - Ei minusta siinä mitään merkillistä ole että joku ottaa kun kerta annetaan. Mutta se että annetaan noin vain, se on tietysti asia erikseen.

- Annetaanko niille sitten niin paljon? kysyi nuori ekonomi.

- Kyllä niille annetaan, vastasi rouva Viita ohimennen katsomatta kysyjään.

(Vartio 1960, 73)

Taiteilijoiden apurahoja koskevassa keskustelussa puhutulle kielelle ominaisia piirteitä edustavat esimerkiksi lisäykset "köyhänähän se kuoli se Kivikin", "taiteilijat ovat aina eläneet köyhyydessä, oikeat taiteilijat" ja viittaaminen henkilöön pronominilla se "vai hulluksiko se tuli?". Sitä vastoin rouva Viidan viimeisen repliikin vastaus kokonaisella lauseella ekonomin kysymykseen ei noudattele uskollisesti puhutun kielen konventioita: "Kyllä niille annetaan" vs. Annetaan tai Joo. Pitkä vastaus implikoi enemmän kuin lyhyt - se indeksoi rouva Viidan ilmaiseman mielipiteen painokkuutta. Taitava leikittely puheen konventioilla lisää ilmaisullisia mahdollisuuksia: Vartion romaanissa luodaan erilaisia sävyjä henkilöiden puheeseen sekä puheen konventioita hyödyntäen että niitä hienovaraisesti modifioiden. ${ }^{6}$

\section{Arvon säeyksikköjen rakentumisen periaatteita}

Nimitän säeyksiköiksi Arvon runojen yhdestä tai useammasta säkeestä rakentuvia kokonaisuuksia, jotka muodostuvat syntaktisin ja/tai semanttisin periaattein. Arvon runoille ominaisten säeyksikköjen teoksen laajuisen kuvauksen tekee mahdolliseksi se, että kaikkien runojen säeyksiköt noudattelevat yhtäläisiä rakentumisen periaatteita: vaikka jokainen runo on yksilöllinen, kaikkien runojen semanttista tasoa yhdistävät tietyt ominaispiirteet, joita käsittelen seuraavaksi tarkemmin.

Arvon runojen säeyksikköanalyysin kiintopisteenä toimii säkeen ja sen lähiympäristön suhde. Säkeen keskeisyys runojen rakenteellisten ominaisuuksien analyysissa johtuu säkeen vakiintuneesta asemasta sekä runon ulkoisena lajitunnuksena että monimerkityksisenä runon rakenneyksikkönä (vrt. Launonen 1984, 12). Vakiintuneena voi myös pitää säkeen määrittymistä suhteessa typografiseen riviin (vrt. Leino 1982, 6263; Launonen, ibid.). Määrittelen Arvon runojen säkeen ei-mitalliseksi runon perusyksiköksi, joka on laajuudeltaan yhden rivin mittainen. ${ }^{7}$ Koska säe on siis visuaalisesti havaittava runon rakenneyksikkö, säkeen sijaan on mahdollista puhua myös säerivistä. Poikkeuksen muodostavat säkeenylitykset, kielell iset yksiköt, jotka jatkuvat säerajan yli (Leino emt., 79). Arvossa säkeenylitykset ilmenevät sisennettyinä, muutamasta sanasta koostuvina säeriveinä.

Toinen säeyksikkö-analyysin kannalta keskeinen komponentti on rytmi. Rytmi, joka on ymmärrettävissä toisteisuudeksi, tulee näkyväksi suhteessa säeriviin. Säerivi edustaa visuaalisesti havaittavaa runon rakenteen säännönmukaisuutta, kun taas rytmi 
edustaa säerivin lähiympäristössä jatkuvasti tapahtuvaa liikettä. Arvon runojen säeyksikköjä analysoitaessa keskeistä on niin säkeensisäinen kuin säerajan ylittävä toisteisuus. Säkeensisäistä toisteisuutta voidaan analysoida esimerkiksi pohtimalla, kongruoivatko säe ja lause. ${ }^{8}$ Esimerkiksi säkeessä "Musta selkä vaan näkyi." (Arvo, 7) säerivi kongruoi yksinkertaisen lauseen kanssa ja muodostaa yhden ortografisen yksikön, virkkeen. Säerajan ylittävien kokonaisuuksien analyysissa on tärkeää kiinnittää huomiota siihen, millaiset rakenteet säerajan ylittävät - onko kyse esimerkiksi syntaktisista tai semanttisista kokonaisuuksista. Säkeet "Äiti oli meilläkin lapsia hoitamassa, / kun minä yritin olla työssä" (Arvo, 22) tarjoavat esimerkin säerajan ylittävästä syntaktisesta, tässä tapauksessa pää- ja sivulauseen muodostamasta kokonaisuudesta.

Lukija tulec tietoiseksi säerajan ylittävistä semanttisista kokonaisuuksista huomatessaan, että Arvon runoissa esiintyy hallitsevasti kahdenlaista toisteisuutta: vuorovaikutuksellisuutta, joka ilmenee näkyvimmin henkilöiden välisinä dialogeina ja kertomuksellisuutta, joka ilmenee menneitä tapahtumia, tilanteita ja kokemuksia välittävinä runonsisäisinä kertomuksina. Vaikka Arvon runojen rakenteelliselle kokonaishahmolle ovat ominaisia myös tietyt visuaaliset piirteet, kuten runsas säkeenloppuinen pilkutus, semanttinen taso on runojen rakenteen kuvauksen kannalta keskeisin. Visuaalinen (typografinen) taso kytkeytyy toki monin tavoin semanttiseen tasoon sitä tukien. Esimerkiksi säejakson vaihdos, joka näkyy tekstissä tyhjänä rivivälinä, osuu runoissa lähes poikkeuksetta semanttiseen siirtymäkohtaan. ${ }^{9}$

Millaisia rakenteellisia kokonaisuuksia, säeyksikköjä, voi sitten hahmotella runoista, joita henkilöiden välinen kommunikaatio ja runonsisäiset kertomukset hallitsevat? Yksi mahdollisuus vastata kysymykseen on ottaa huomioon Arvon puheenomaisuus myös runojen rakenteen analyysissa. Seuraavaksi tarkastelen, millaisia säeyksikköjä runosta löytyy lausuma-analyysin avulla.

On se vaan semmosta ettei moni tiedä.

Kerran taas katulamppu läikkyi niin tossa kohdalla, nehän koettavat sanoa sekin oli lamppua.

Ja hyvä on jos oli,

minä en tykkää nähdä mitään,

minä pelkään koko öitä nykyisin,

ettei vaan tulis lähelle joku lopulta, ja ettei puhuis.

1 Silloin niin kaunis nainen oli ikkunan takana,

2 niinkuin se yks hoitaja, mut oli nuori ja kaunis,

3 kuin päivä sen naama, posket punaiset,

4 ja suu hymyssä, suurenpuoleinen suu, mut nätti.

5 Minä nousin istumaan ja ajattelin "Mitäs siihen tulit

7 viidenteen kerrokseen, vahtimaan,

8 minä tulen keppini kanssa, etköhän lähde 
ojen säeyktoisteisuus. gruoivatko ivi kongru1, virkkeen. iota siihen, ai semanttiminä yritin , tässä tapa-

sta huoma: vuorovaiia ja kertoa välittävinä ishahmolle inen pilkuVisuaalinen tukien. Esinoissa lähes

ella runoishallitsevat? enomaisuus zsikköjä ru-
9 oman miehes tykö",

10 mut sehän oli vanhapiika, sitä en muistanut.

11 Se hävis siinä sitten,

12 minä sanoin "Ettei vaan mennyt tonne

13

14 vaari on siellä". kylpyhuoneeseen,

15 Nääs nyt, ja minä nostin ja nostin tota seinävaatetta,

16 täytyy mitähän ne oikein tekevät siellä,

17 koetin kurkata,

18 hoitajakin tuli siihen ja sanoi, että naulat lähtee.

19 "Mutta kun meidän on siellä" minä sanoin,

20 "Ei teidän sen sermin takana ole", se sanoi ja sytytti

21 valon,

22 "nukutaan pois".

[--] (Arvo, 43-44)

Lausumat ovat puheessa esiintyviä kommunikatiivisia ja toiminnallisia kokonaisuuksia, jotka voivat olla esimerkiksi lauseen muotoisia, käsittää yhden tai useamman lausekkeen tai muodostua partikkelista. Lausuma eroaa kieliopillisesti määriteltävissä olevasta lauseesta siten, että kyseessä on "puhujan määrätilanteessa muotoilema tekstin osa". Tässä suhteessa lausuma vastaa kirjoitetun kielen virkettä; "kummankaan kieliopillinen määrittely ei ole a priori mahdollista". ${ }^{10}$ Lausumat ovat pragmaattisia kokonaisuuksia, jotka keskustelussa muodostavat "(puheen)vuoron tai sellaisen osan". Lausumilla puhujat siis suorittavat erilaisia toimintoja. Tällaisia puhetoimintoja ovat esimerkiksi reaktio edeltävään vuoroon tai vastaus kysymykseen. (ISK, 957; 827.) ${ }^{11}$ Käytännössä yllä olevan runon lausuma-analyysi tarkoittaa, että analysoin runoa puhetilanteena, joka rakentuu tietyistä toiminnallisista ja kommunikatiivisista kokonaisuuksista. Lausumaanalyysi toimii välineenä, jonka avulla voi löytää puheenomaisen runon säeyksikköjä ja tutkia niiden rakentumisen periaatteita: kursivoinnilla runoon merkitsemäni säeyksikköjen rajat ovat tulos, johon olen lausuma-analyysin avulla päätynyt.

Runo sisältää kertomuksen, jonka aiheena on sairaalassa koettu harha kauniista naisesta, jonka vanhaäiti epäilee yrittävän vietellä vaarin, hänen miehensä. Runon puhetilanne, vanhaäidin kertoma harhakertomus, jaksottuu erilaisiksi kertomusta eteenpäin vieviksi vaiheiksi. Runon alku eli ensimmäinen säejakso on johdanto, jossa harhakertomusta alustetaan. Varsinaisessa harhakertomuksessa, jonka säkeet olen numeroinut, kuvataan ensin vanhaäidin näkemä harha (r. 1-4). Rivien 5-9 säkeiden muodostaman vanhaäidin repliikin johtoilmaus "minä nousin istumaan ja ajattelin" kertoo, miten vanhaäiti reagoi nähtyyn harhaan.

Olen merkinnyt repliikin yhdeksi säeyksiköksi sillä perusteella, että se muodostaa johtoilmauksineen selkeän kommunikatiivisen kokonaisuuden. Säeyksikköjen rajat eivät kuitenkaan aina noudattele lausumien rajakohtia, vaikka säeyksikköjä lausuma- 
analyysin avulla hahmottelenkin. Esimerkiksi tässä nimenomaisessa kohdassa säeyksikkö sisältää kaksi lausumaa. Rivien 5-7 säkeet muodostavat ensimmäisen lausuman, joka on funktioltaan puhuttelu: vanhaäiti puhuttelee ajatuksissaan harhaa. Rivien 8-9 säkeet muodostavat järjestyksessä toisen ja toisenlaisen puhetoiminnon, harhalle esitetyn uhkauksen. Säeyksikkörajan ja lausumien suhde on repliikissä hierarkkinen: suurempaan toiminnalliseen kokonaisuuteen, repliikkiin, sisältyy sävyn vaihdos. Rivin 10 säe muodostaa oman säeyksikkönsä sillä perusteella, että adversatiivisella mut(ta)-konjunktiolla alkava säe on funktioltaan vanhaäidin oman ajattelun korjaus: hän muistaa kauniin naisen vanhaksipiiaksi toisin kuin suorassa esityksessä edellä ilmaistu ajatus "etköhän lähde oman miches tykö" antaa ymmärtää.

Kolmannessa säejaksossa runo jatkuu kerronnallisena. Säejakson vaihdos tukee tässä semanttista siirtymää: harhaa kuvailevasta jaksosta siirrytään toiminnallisempaan jaksoon. Jaksossa kerrotaan harhan katoamisesta (rivin 11 säeyksikkö) sekä siitä seuraavista tapahtumista. Rivien 12-14 säkeiden muodostaman säeyksikön, vanhaäidin repliikin, johtoilmaus "minä sanoin" ilmaisee, että vanhaäiti reagoi käänteeseen, harhan katoamiseen, sanomalla jotakin. Rivin 15 säkeen muodostama säeyksikkö esittää kertomuksen seuraavan vaiheen: vanhaäiti yrittää etsiä kaunista naista seinävaatteen takaa. Rivin 16 säeyksikkö, joka on vanhaäidin ajattelun vapaata suoraa esitystä, ilmentää vanhaäidin ajatuksia hänen nostaessaan seinävaatetta. Myös tässä säeyksikköraja ja lausumaraja eriävät: säerivin mittainen säeyksikkö on puheen vapaata suoraa esitystä, mutta vapaa suora esitys sisältää kaksi lausumaa. Ensimmäinen niistä muodostuu ilmauksesta "täytyy", ja toisen muodostaa ilmaus "mitähän ne oikein tekevät siellä". Jälkimmäinen puhetoiminto on puhujan itsekorjaus, joka indeksoi kiireen ja hätääntymisen tuntemuksia. Neljännessä vaiheessa, rivin 17 säeyksikössä, edetään seinävaatteen nostamisesta yritykseen kurkistaa sen taakse. Viidennessä vaiheessa, rivin 18 säkeessä, hoitaja tulee paikalle. Rivien 19-22 säkeet koostuvat hoitajan ja vanhaäidin dialogista ja muodostavat harhakertomuksen lopun.

Lausuma-analyysi toimii siis välineenä, jonka avulla voi löytää puheenomaisen runon säeyksikköjä ja tutkia niiden rakentumisen periaatteita. Lausuma-analyysilla on toinenkin merkitys. Funktioltaan erilaisten ja toisiaan seuraavien puhetoimintojen eli lausumien avulla huomio kiinnittyy siihen, miten Arvon runojen säeyksiköt "ovat liikkeessä": säeyksikköjen liikkuvarajaisuus aktuaalistuu, kun niiden rajat ymmärretään runonsisäisten semanttisten siirtymäkohtien rajoiksi. Tällöin olennaista ei ole niinkään se, minkälaajuinen kulloinenkin säeyksikkö on, vaan se, mitä säeyksikössä ja sen rajoilla tapahtuu. Säeyksikköjen rajat voidaan siis ajatella erilaisiksi toiminnallisiksi siirtymiksi esimerkiksi kertomuksen vaiheesta toiseen tai siirtymiksi vanhaäidin puheesta jonkin toisen henkilön puheen esittämiseen. Kyse voi olla myös hienovaraisemmista siirtymistä, jotka ilmentävät puhujan reaktiota tai asennetta juuri kerrottuun tilanteeseen tai 
assa säeyk-

lausuman, Rivien 8-9 halle esitexinen: suus. Rivin 10 $u t(t a)$-konän muistaa aistu ajatus s tukee täsdlisempaan :ä siitä seuvanhaäidin eseen, harkkö esittää inävaatteen zstä, ilmensikköraja ja oraa esitysmuodostuu evät siellä”. a hätääntyinävaatteen 8 säkeessä, n dialogista maisen rualyysilla on nintojen eli t"ovat liiknmärretään le niinkään sen rajoilla siirtymiksi esta jonkin ta siirtymisateeseen tai kokemukseen. ${ }^{12}$

Arvon säeyksikkö-analyysia kehystääkin laajemmassa perspektiivissä vapaarytmisen runouden yleisempi problematiikka, jonka Auli Viikari $(1987,51)$ kiteyttää väitöskirjassaan kysymykseen "mikä konstituoi vapaarytmisen säkeen". Kysymys haastaa pohtimaan säkeen merkitystä ja tehtävää vapaarytmisessä runossa, jonka säe ei määrity mitan sanelemin ehdoin ja jonka rakenteellista hahmoa eivät ohjaile välttämättä kovinkaan helposti havaittavat säännönmukaisuudet. Arvon säeyksikköjen rakentumisen periaatteet ovat yksi avaus vapaarytmisen runon rakenteelliseen analyysiin. Säkeen ja säcyksikön suhteen tarkastelu osoittaa, että säe ja yhdestä tai useammasta säkeestä semanttisin perustein koostuvat säeyksiköt ovat kaksi eri asiaa. Säe tarjoaa runon rakenteen analyysin kannalta välttämättömän, tarpeeksi stabiilin lähtökohdan. Säeyksiköt puolestaan ovat liikkuvarajaisia yksikköjä, joiden rakentumisen periaatteita analysoimalla voidaan saada vastauksia siihen, mitä Arvon runoissa "on tekeillä". Arvon säeyksikköanalyysi osoittaa, että runon sisäinen rytmi voi olla semanttisesti rakentuvaa rytmiä.

\section{Runojen väliset kytkennät ja puheen esittämisen merkitys}

Säeyksikköjen rajojen hahmottaminen semanttisiksi siirtymiksi on ilmiö, joka laajenee runonsisäisistä suhteista runojen välisiin suhteisiin. Runojen väliset semanttiset siirtymät kytkevät Arvon runot näyttämöiksi, jotka esittävät vanhaäidin elämäkerran vaiheita. Sekä runonsisäiset kertomukset että runonäyttämöt ovat teoksen rakennetta rytmittäviä elementtejä.

Arvosta voidaan erottaa seuraavanlaisia kahdesta tai useammasta runosta koostuvia näyttämöitä: perhesuhteita esittävä näyttämö, näyttämö, jossa esitetään elämää sen jälkeen kun kotitalo on tuhoutunut sodanaikaisessa pommituksessa, hoitajasuhteita ja nuoruudenaikaisia piikomissuhteita esittävät näyttämöt sekä sairaana koettuja harhaaistimuksia ja pelkoja esittävä näyttämö. Edellä analysoimani runo on siis yksi harharunojen näyttämön neljästä runosta ja runoon sisältyvä harhakertomus yksi Arvon harhakertomuksista.

Näyttämömallinnuksen mukaisesti yksittäiset runot hahmottuvat kohtauksiksi laajemman semanttisen kehyksen, tiettyä elämäkerrallista osa-aluetta esittävän näyttämön, sisällä. Runojen väliset siirtymät ovat siirtymiä joko kohtauksesta toiseen tietyn näyttämön sisällä tai näyttämöltä toiselle. Runojen kytkeytyminen tietyllä runonäyttämöllä ei noudattele kronologista jatkumoa, vaan yksittäinen runo on sisällöltään yllätyksellinen suhteessa sitä edeltävään runoon. Kuitenkin jokainen runo on jollain tavalla kytköksissä jo edellisissä runoissa rakentuneeseen fiktiivisen elämäkerran kuvastoon. Myös siirtymät runonäyttämöltä toiselle ovat siinä mielessä satunnaisia, että ne eivät toteuta minkäänlaista teoksen laajuista kronologista periaatetta.

Jörgen Larsson, joka on pohtinut runon semanttisen rytmin olemusta, on nimen- 
nyt yhdeksi semanttisen rytmin alalajiksi montadsirytmin (montagerytm). Montaasirytmillä Larsson viittaa elokuvasta lainaamaansa ilmiöön, joka rytmittää runon semanttisen tason eräänlaiseksi kuvien sarjaksi. Hänen mukaansa montaasirytmin funktio on elävöittää fiktiivisen teoksen miljöötä ja tilanteita. Kyse voi myös olla enemmän tai vähemmän äkkinäisistä siirtymistä paikasta, henkilöstä tai tilanteesta toiseen. (Larsson 1995,45 .) Myös Arvon runojen välisiä semanttisia siirtymiä runonäyttämöllä tai näyttämöltä toiselle voi luonnehtia elämäkerrallisiksi leikkauksiksi ja tässä mielessä montaasimaisiksi. Samalla niitä voi luonnehtia metonyymisiksi, sillä yksittäiset runot edustavat elämäkerran fragmentteja, joiden kautta niin ikään fragmentaariseksi jäävä elämäkerran laajempi kuva rakentuu. Tämän samaisen asioiden välisen metonyymisen suhteen on ilmaissut Tynjanov (2001, 309), joka elokuvan montaasia luonnehtiessaan kirjoittaa, että "otokset eivät kata tyhjentävästi kokonaisia tarinoita, vaan "edustavat" niitä otosten kokonaisuudessa”. ${ }^{13}$

Siitä huolimatta, että näyttämöiden sisäiset ja väliset siirtymät ovat montaasimaisia ja elämäkertaa metonyymisesti rakentavia, runojen välisten kytkentöjen on oltava riittäviä, jotta miclikuva runojen näyttämöllisyydestä toteutuu. Arvon runojen välisiä kytkentöjä voidaankin pitää vahvoina, koska ne toteutuvat sekä semanttisin että grammaattisin periaattein. ${ }^{14}$ Semanttiset kytkennät toteutuvat muun muassa siten, että tietyn näyttämön kuvastoa, esimerkiksi henkilöitä, paikkoja ja tilanteita, kierrätetään runosta toiseen. Arvon harharunojen näyttämön runoja yhdistävät toisiinsa sairaala, tyttären ja hoitajien läsnäolo kerrotuissa tilanteissa ja yhtäläinen elämäntilanne, aivohalvauksesta toipuminen. Keskeisin yhdistävä tekijä on pelkotilojen ja harha-aistimusten kertominen.

Vaikka Arvon runonäyttämöt eivät muodosta kronologisesti etenevää jatkumoa suhteessa toisiinsa, ne eivät ole vailla järjestystä. Kuten montaasitekniikalla elokuvassa myös Arvon runojen montaasimaisuudella on merkitystä teoskokonaisuuden kannalta. Mikä on sitten Arvon elämäkerrallisten leikkausten logiikka? Mikä merkitys näyttämöittäin etenevällä puheen esittämisellä on Arvon teoskokonaisuuden kannalta? Vastaus vaatii tutustumista Arvon kursivoituun avausrunoon. ${ }^{15}$

Kun ei enää voi mitään tebdä, ei mitään,

maata tässä ja nousta välillä istumaan,

käydä pöydässä ja tuolla; edes ikkunasta en paljon jaksa

katsella.

Yritän joskus ja siihen se jää.

Tulen takaisin, beitän pitkälleni.

Sama minulle, kuka siellä menee, ja minne.

Mitä tekevät. 
MontaasirytInon semantin funktio on enemmän tai jiseen. (Larsiyttämöllä tai ässä mielessä ittäiset runot ariseksi jäävä letonyymisen nnehtiessaan n "edustavat"

nontaasimaijen on oltava runojen välihanttisin että ssa siten, että , kierrätetään insa sairaala, tilanne, aivorha-aistimusla elokuvassa den kannalta. kitys näyttäannalta? Vas-
Arvon avausruno on teoksen ainoa kokonaan nykyhetkeen kohdistava preesensınuotoinen runo. Arvossa, jossa imperfekti on hallitseva aikamuoto, preesens-tempuksen käyttö on kohosteista. Tosin preesensiä esiintyy myös neutraaleissa yhteyksissä. ${ }^{16}$ Erityisen merkityksellisiä ovat tapaukset, joissa esitetään preesensmuotoisin ilmaisuin ja teoksen nykyhetken origosta käsin vanhaäidin mentaalista tilaa ja fyysistä rajoittuneisuutta. Kummatkin tapaukset ovat edustettuina jo avausrunossa, joka kohdistaa huomiota vanhaäidin rajoittuneeseen fyysiseen liikkuma-alaan ja turhautuneeseen mielentilaan: "sama minulle, kuka siellä menee, ja minne". Avausruno asettaa vanhaäidin puheen heti teoksen alussa tiettyyn kehykseen: se motivoi Arvossa keskeisen muistin maailman. Motivointi toteutuu negaation kautta kaventamalla ja rajoittamalla nykyhetkeä fyysisesti ja mentaalisesti sillä seurauksella, että mennyt maailma näyttäytyy teoksessa alusta alkaen nykyhetkeä mielekkäämpänä ja sisällöllisesti rikkaampana aikaulottuvuutena. Lukijan kannalta avausruno toimii kehystekstin tavoin, luennan ohjeistuksena - se näyttää, tiivistää ja samalla pohjustaa sellaisia nykyhetkeen liittyviä tuntemuksia, jotka osoittautuvat myöhemmin teoksessa keskeisiksi.

Runon suhde muihin teoksen runoihin avautuu näyttämömallinnuksen avulla. $A r$ von alkupuoliskolla edetään perhesuhteiden näyttämöltä sodanjälkeistä elämää esittävälle näyttämölle. Kummallakin näyttämöllä temporaalinen painopiste on menneessä ajassa. Sodanjälkeisen elämän kertomisesta siirrytään hoitajarunoihin, piikomisrunoihin ja teoksen lopussa harharunoihin. Keskeistä on, että teoksen nykyhetkeen fokusoidaan Arvon alkupuoliskon runoissa harvakseltaan. Varsinaisesti vasta harharunoissa esitetään vanhaäidin nykyhetkisiä tunteita: tunteiden esittämisessä on avausrunon ja teoksen loppupuoliskon runojen välillä tauko, ja lukijaa ohjastaa teoksen luennassa avausrunon vanhaäidin nykyhetkisen tilan fyysis-psyykkinen tiivistelmä. Niin ikään avausrunossa esitetty fyysinen rajoittuneisuus täydentyy vasta teoksen loppupuoliskon runoissa muistin ja näön heikkenemisellä: "en tiedä minun muistini ei tahdo pitää enää" (Arvo, 32); "En näc oikein. / Lyö kirjaimet sekaisin" (Arvo, 41). Muistin heikkenemistä ilmaiseva runo sisältyy hoitajarunojen ja näön heikkenemisestä kertova runo harharunojen näyttämölle.

Jo edellä osin siteeraamani Arvon viimeinen runo on tunteiden esittämisen kannalta keskeinen. Runon viimeinen, neljäs säejakso on seuraavanlainen.

Puhuttiin siitä Liisalle molemmat omalla tavallamme,

Liisa sanoi "Onks äidillä ikävä".

Onhan se, ei tabdo muuta ollakadn, vaikka itken ja

kun minä pääsisin pois. nauran tässä;

Mut kai täällä täytyy jokaisel olla vuoronsa.

Kun itken aikani kuluks, niin ajattelen menee se aika täytyy sen lopulta mennä.

Enhän minä tänne maailmanpatsaaks jää. (Arvo, 43-44) 
Edellisessä luvussa analysoimaani imperfektimuotoista harhakertomusta ympäröi runon ensimmäisen ja neljännen säejakson preesensmuotoinen tunteiden esittäminen. Runon alku "On se vaan semmosta ettei moni tiedä" kutsuu lukijan vastaanottamaan pian esitettäviä tunnetiloja ja ahdistavia kokemuksia. Ensimmäinen säejakso tuo esiin öisen harhojen näkemisen pelon: "minä pelkään koko öitä nykyisin, / ettei vaan tulis lähelle joku lopulta, ja ettei puhuis". Neljännessä säejaksossa ilmaistuja tunteita ovat ikävä ja turhautuneisuus. Ikävän esittämistä kohostaa sen ilmaiseminen vanhaäidin ja Liisa-tyttären välisessä dialogissa. Dialogi (kursivoitu) muodostuu Liisan menneenä ajankohtana ilmaisemasta kysymyksestä ja vanhaäidin vastauksesta, joka sijoittuu aja! lisesti teoksen nykyhetkeen. Kun aikatasot yhdistyvät, spesifissä tilanteessa esitetryyn kysymykseen annettu vastaus siirtyy kuvaamaan myös nykyhetkeä värittävää tunneita. Turhautumisen tunnetta ilmentävät puolestaan runon lopun ajatukset itkemisestä ajan kuluksi. Runon lopussa vanhaäiti ilmaisee voimakkaan toiveensa päästä pois. Toive kiteytyy typografisestikin muusta runosta erotetussa loppulauseessa "Enhän minä tänne maailmanpatsaaks jää."

Preesensmuotoinen turhautumisen tunteiden esittäminen sitoo Arvon viimeisen runon avausrunoon: viimeisessä runossa ajan kuluttamisesta itkien ja kuoleman odotuksesta tulee nykyhetkessä olemisen modus. Lisäksi hautamotiivi, joka on keskeinen harharunojen näyttämöllä, esiintyy ensimmäisen kerran jo teoksen alussa, avausrunoa seuraavassa runossa. Se alkaa sanoin: "Kerranhan minä olin olevinaan kuollutkin ja vaarin vieressä." Runossa kerrotaan vanhaäidin tuntemasta hädästä, kun vaari etenee tavoittamattomiin ja jättää vanhaäidin yksin. Harharunojen näyttämön runoja kytkee mainittuun runoon miehen menettämisen pelko. Harharunoissa se ilmenee vanhaäidin pelkona, että hän joutuu haudatuksi väärän miehen viereen ja pelkona, että vaari vietellään.

Näyttämöllinen puheen esittäminen palvelee siis Arvossa sekä teoksen sisäistä vanhaäidin maailman rakentumista että retorisia tarkoitusperiä. Teoksen maailman näkökulmasta katsottuna runonäyttämöt esiträvät elämäkerran vaiheita ja tallentavat vanhaäidille arvokasta mennyttä arkea. Retorisesta näkökulmasta Arvon alun ja lopun yhteistyö, näyttämöllinen rakenne ja preesens-tempuksen harkitut esiintymät rakentavat teoskokonaisuudesta käsin keskeistä vanhaäidin tunteiden esittämistä. Retoriset tarkoitusperät voidaan kiteyttää pyrkimykseksi esittää yksinäisen ja vieraantuneen vanhuksen arkea, joka jää nostalgisen menneen elämän muistamisen ja kuolemanodotuksen puristukseen. Retorisesta näkökulmasta katsottuna elämän näyttämöllinen esittäminen montaasimaisina leikkauksina kuvastaa myös muistin hajoamista, joka tuodaan esiin sivun 32 runossa: "en tiedä minun muistini ei tahdo pitää enää". 
npäröi ru-

ittäminen.

nottamaan

o tuo esiin

i vaan tulis

nteita ovat

thaäidin ja

menneenä

oittuu ajal-

esitettyyn

ä tunnetta.

hisestä ajan

s. Toive ki-

ninä tảnne

viimeisen

eman odo-

keskeinen

avausrunoa

tollutkin ja

aari etenee

noja kytkee

ee vanhaäi-

, että vaari

isäistä van-

ailman nä-

tallentavat

in ja lopun

\section{Lopuksi}

Maila Pylkkösellä on keskeinen asema säemuotoisen ja puheenomaisen monologin kehittäjänä suomenkielisessä lyriikassa. Tässä artikkelissa olen esittänyt muutaman näkökulman siihen, mitä kaunokirjallisen tekstin puheenomaisuus on ja miten se ilmenee Arvossa. Ensimmäisessä analyysiluvussa tarkastelin lausuma-analyysin avulla, millaisin periaattein Arvon runoille ominaiset säeyksiköt rakentuvat. Esitin, että säeyksiköiden rakentumista säätelevät kommunikatiiviset ja toiminnalliset perusteet. Esitin lisäksi, että lausuma-analyysin kautta säeyksikköjen rajat näyträytyvät semanttisten siirtymäkohtien rajoina. Toin myös esiin, että Arvon liikkuvarajaisten säeyksikköjen analyysi on yksi avaus vapaarytmisen runon rakenteelliseen analyysiin yleisemminkin. Toisessa analyysiluvussa laajensin näkökulmaa säeyksiköistä runojen välisiin semanttisiin kytkentöihin ja totesin, että Arvon runot muodostavat elämäkerrallisia vaiheita esittäviä näyttämöitä. Runonäyttämöiden funktio on teoksessa kahtalainen. Ensiksikin ne rakentavat metonyymisesti vanhaäidin fiktiivisen ja fragmentaariseksi jäävän elämäkerran kuvaa. Toiseksi teoksen näyttämöllisen rakentumisen kautta nostetaan etualalle vanhaäidin ikävän ja vieraantumisen tunteita, jolloin näyttämöittäin etenevä puheen esittäminen saa retorisia merkityksiä.

Pyrkimykseni on ollut osoittaa artikkelin edetessä, miten monisyistä Arvon puheenomaisuus on. Vaikka puhekielisyydet edustavat teoksen helpoimmin havaittavaa puheenomaisuutta, niistä on päästävä eteenpäin: puhutun kielen piirteet ja monologimuodon kohostama puhujan ja puhetilanteen keskeisyys ovat keinoja pyrkiä uskottavaan puheen vaikutelmaan, joka puolestaan kutsuu lukijaa samastumaan vanhaäidin maailmaan, tunteisiin ja kokemuksiin. Arvo vaikuttaa lukijaan puhetta esittämällä: vanhaäidin persoonallinen puhe voi herättää lukijassa myötätuntoa, ja lukija voi mieltää vanhuksen arjen arvokkaaksi, siis kertomisen arvoiseksi, asiaksi.

\section{Viitteet}

' Teoksen Ilmaa puhuja on pieni tyttö ja Valta koostuu lehtorinrouvan ja näyttelijättären monologeista. Teoksen Ilmad alaotsikko on kaksoiskokoelman Ilmad Kaikuu paperikannessa Runomittainen monologi, sisäsivulla Monologi ja teoksen omalla nimiölehdellä Pienen tytön runot. Teoksen Valta alaotsikko on Lehtorinrouva. Näyttelijätär. Pronssiveistos.

${ }^{2}$ Ks. tarkemmin jälkituotannon teosten runouskäsityksistä Seutu 2004 ja Hökän Pylkkösen runoutta käsitrelevät artikkelit.

${ }^{3}$ Puheenomaisen runouden traditiota ei ole kuirenkaan jäljitetty lukuunottamatta Viikarin (1983; 1985) tutkimuksia Joel Lehtosen runouden puheenomaisuudesta.

${ }^{4}$ Esim. Launonen 1984; Enwald 1997; Kaunonen 2001.

${ }^{5}$ Ks. esim. Leino 1982; Hakulinen 1988; Kalliokoski 1989; 1991; 1998; Laitinen 1998; 
Lankinen 2001.

${ }^{6}$ Nämä Vartion dialogin puheenomaisuuden aspektit tulivat esiin Auli Hakulisen kurssilla. Puhutun ja kirjoitetun kielen piirteitä (HY, kevät 2005).

${ }^{7}$ Säe on alkujaan mitan yksikkö (vrt. esim. Leino 1982, 62), joka on vakiintunut käsitteenä myös modernin runon rakenneyksiköstä puhuttaessa.

${ }^{8}$ Viikari $(1987,46$; 47-48) mainitsee säkeen ja lauseen kongruenssin normaalitapaukseksi, jota vasten esimerkiksi säkeenylitys näyträytyy poikkeavana. Viikarin väitöskirja (etenkin siihen sisältyvä runokielen rytmisen komponentin fonologinen, grammaattinen ja pragmaattinen kuvausmalli) on ollut Arvon säeyksikköanalyysin esikuvana.

${ }^{9}$ Samansuuntaisen havainnon on tehnyt myös Jörgen Larsson $(1995,38)$, joka korostaa semanttisen tason keskeisyyttä.

${ }^{10} \mathrm{Vrt}$. lause, joka on "sanoista ja lausekkeista muodostuva rakenteellinen kokonaisuus, jonka ytimenä on verbin persoonamuoto eli finiittiverbi ja jonka osien välillä vallitsee erilaisia riippuvuus- ja määrityssuhteita" (ISK, 827).

${ }^{11}$ Puhetoimintaa on se, "mitä puhetilanteissa tapahtuu". Puhetilanteessa voi olla useita puhetoimintoja. Tällaisia ovat esimerkiksi kertominen, kuvittelu, kysyminen ja kommentointi. (Hakulinen 1989, 51-72.)

${ }^{12}$ Vrt. Goffmanin (1981) tutkimus puhujan asennon vaihdoksista (change in footing), jotka ovat aktuaalisia puhetapahtumia laajasti luonnehtivia puhujan suorittamia siirtymiä, näkökulman muutoksia. Ks. myös Viikari 1987.

${ }^{13}$ Ks. myös Haapala (2005, 54-55), joka hyödyntää montaasimaista jäsennystä selvittäessään Södergranin runonsisäisiä ja runojen välisiä suhteita.

${ }_{14}$ Grammaattiset kytkennät toteutuvat ennen kaikkea runonalkuisten partikkelien ja, mutta ja no osoittamien kytkentöjen kautta. Kielenturkijat ovat kiinnittäneet huomiota siihen, että kirjoitetussa tekstissä partikkelit toimivat puheenomaisina aineksina ja tuottavat puheen vaikutelmaa (Kalliokoski 1998, 193).

${ }^{15}$ Ulkoisesti runosta tekee avausrunon kursivoinnin lisäksi se, että teoksen sivunumerointi alkaa juosta vasta seuraavan runon kohdalla. Lisäksi avausrunoa ja sitä seuraavaa runoa erottaa tyhjä välilehti.

${ }^{16}$ Preesensin neutraalia käyttöä edustavat puheen suoran esityksen preesens, yleisempien asiaintilojen ilmaisemisen preesens (vrt. "kaikki ihmiseltä häviää" (Arvo, 13)) sekä preesens, jolla ilmaistaan nykyisyyden aikaulottuvuudessa toisteisia asioita (esimerkiksi, että lapset käyvät lähes joka päivä $($ Arvo, 16)).

\section{Lähteet}

\section{Maila Pylkkösen teokset}

1957: Klassilliset tunteet. Runoja. Helsinki: Otava.

1958: Jeesuksen kylä. Runoluonnos. Helsinki: Otava.

1959: Arvo. Vanhaäiti puhuu runonsa. Helsinki: Otava.

1960: Ilmaa. Runomittainen monologi. Monologi. Pienen tytön runot. Kaikuu. Runoja. Helsinki: Otava.

1962: Valta. Lehtorinrouva. Näyttelijätär. Pronssiveistos. Helsinki: Otava. 
1965: Virheitä. Helsinki: Otava.

1970: Tarina tappelusta. Helsinki: Otava.

1972: Muistista. Proosaa ja runoa. Helsinki: Otava.

1975: Marjamiesnaisen muistiinpanoja. Helsinki: Otava.

1976: Monologit. Helsinki: Otava.

1977: On kesä vain. Runoja. Helsinki: Otava.

1983: Kootut. Runot ja proosarunot 1957-1977. Helsinki: Otava.

\section{Tutkimuskirjallisuus}

ENWALD, LIISA 1997: Kaiken liikkeessä lepo. Monihabmotteisuus Mirkka Rekolan runoudessa. Helsinki: SKS.

goffman, erving I 98 I: Forms of Talk. Philadelphia: University of Pennsylvania Press. hAAPALA, VESA 2005: Kaipaus ja kielto. Edith Södergranin Dikter-kokoelman poetiikkaa. Helsinki: SKS.

HAAVIKKO, PAAVO I 95 5: Synnyinmaa. Runoja. Helsinki: Otava.

HAKULINEN, AULI I989: Keskustelun luonnehtimisesta konteksti- ja funktionaalisten tekijöiden nojalla. Teoksessa Kieli 4. Suomalaisen keskustelun keinoja I. Toim. Auli Hakulinen. Helsinki: Helsingin yliopiston suomen kielen laitos. 41-72.

HAKULINEN, AULI I988/200 I Miten nainen liikkuu Veijo Meren romaaneissa. Teoksessa Lukemisto. Kirjoituksia kolmelta vuosikymmeneltä. Toim. Lea Laitinen, Pirkko Nuolijärvi, Marja-Leena Sorjonen \& Maria Vilkuna. Helsinki: SKS. 299-312.

HÖKKä, TUULA 1987: Runous muuttaa muotoaan. Turun Sanomat. 7.2.1987

HÖKкÄ, TUULA 1989: Modernismista hernesopan lyriikkaan - Maila Pylkkönen. Teoksessa "Sain roolin johon en mahdu". Suomalaisen naiskirjallisuuden linjoja. Toim. MariaLiisa Nevala. Helsinki: Otava. 617-627.

HÖKкÄ, TUUlA 1992: Mopeda meillekin! Naisrunoilijoita modernismissa. Teoksessa Avoin ja Suljettu. Kirjoituksia 1950-luvusta suomalaisessa kulttuurissa. Toim. Anna Makkonen. Helsinki: SKS. 78-92.

нӧккÄ, тUULA I999: Modernismi: uusi alku - vanhan valtaus. Teoksessa Suomen kirjallisuushistoria 3. Rintamakirjeistä tietoverkkoibin. Toim. Pertti Lassila. Helsinki: SKS. 68-89.

нӧккё, тUUla 200 I (tulossa): Maila Pylkkönen. Suomen kansallisbiografia. Helsinki: Suomen historiallinen seura. Verkkojulkaisu: www.kansallisbiografia.fi.

ISK = Auli Hakulinen, Maria Vilkuna, Riitta Korhonen, Vesa Koivisto, Tarja Riitta Heinonen \& Irja Alho, Iso suomen kielioppi. Helsinki: SKS. 2004.

KALLIOKOSKI, JYRKI 1989: Ja. Rinnastus ja rinnastuskonjunktion käyttö. Helsinki: SKS.

KALLIOKOSKI, JYRKI I99I: Keskustelu, linearisaatio ja näkökulma. Teoksessa Miten valehdellaan. KTSV 45. Toim. Markku Ihonen. Helsinki: SKS. 157-174.

KALLIOKOSKI, JYRKI 1998: Hjalmar Nortamon murrekertomukset ja puhutun illuusio. 
Teoksessa Sanan voima. Keskusteluja performatiivisuudesta. Toim. Lea Laitinen ja Lea Rojola. Helsinki: SKS. 184-215.

KAUNONEN, LEENA 200I: Sanojen palatsi. Pubujan määrittely ja teoskokonaisuuden bahmotus Padvo Haavikon Talvipalatsissa. Helsinki: SKS.

LAITINEN, LEA I 998: Dramaattinen preesens poeettisena tekona. Teoksessa Sanan voima. Keskusteluja performatiivisuudesta. Toim. Lea Laitinen ja Lea Rojola. Helsinki: SKS. 81-136.

LANKINEN, PASI $200 \mathrm{I}$ : Ajatus kuluttad kiveä. Mitan eroosio Juha Mannerkorven lyriikassa. Helsinki: SKS.

LARSSON, JÖRGEN 1993/I995: Semantisk rytm. Rytmen i Fokus. Studier framlagda vid Fjärde nordiska metrikkonferensen Lund 25-27 november 1993. Utgivna av Sven Bäckman, Eva Lilja \& Bengt Lundberg. Göteborg: Skrifter utgivna av Centrum för Metriska Studier 6.37-49.

LAUNONEN, HANNU 1984: Suomalaisen runon struktuurianalyysia. Tutkimus Jaakko Juteinin, Aleksis Kiven, Otto Mannisen, Eino Leinon, V. A. Koskenniemen, Uuno Kailaan, Kaarlo Sarkian, Tuomas Anhavan, Paavo Haavikon ja Pentti Saarikosken lyriikasta. Helsinki: SKS.

LEINO, PENTTI 1982: Kieli, runo ja mitta. Suomen kielen metriikka. Helsinki: SKS.

polkunen, Mirjam I959: Maila Pylkkönen: Arvo. Uusi Suomi. 20.12.1959

SEUTU, KATJA 2004: Runo kuin puhetta, runo kuin muistikirja. TuliðSavu 3/2004. $41-47$.

TYNJANOV, JURI I 927/200I: Elokuvan perusteista (Ob osnovah kino). Teoksessa Venäläinen formalismi. Antologia. Toim. Pekka Pesonen ja Timo Suni. Helsinki: SKS. 295-320.

VARTIO, MARJA-LIISA I960: Kaikki naiset näkevät unia. Romaani. Helsinki: Otava. VIIKARI, AULI I98I: Lähimmäinen kieli. Parnasso 8/1981. 195-200.

viIKari, AUlI 1983: Proosan kuriton kulku ja henki. Teoksessa Kirjojen meri. Professori Annamari Sarajaksen jublakirja 12.10.1983. Helsinki: SKS. 270-285.

VIIKARI, AULI I985: Runon ahdinko ei riitä. Joel Lehtosen Nurkka-Massin kuuliaisten rytmiikkaa. KTSV 38. Toim. Anna Makkonen. Helsinki: SKS. 109-125.

vIIKARI, AULI 1987: Ä̈neen kirjoitettu. Vapautuvien mittojen varhaisvaiheet suomenkielisessä lyriikassa. Helsinki: SKS. 